\title{
Collaborative Responsibility in Teacher Preparation: Student Teachers' Perceptions of the Role of Schools in Their Professional Development in Zambia
}

\author{
Kenneth Kapalu Muzata \\ Department of Educational Psychology, Sociology and Special Education, University of Zambia, Lusaka, Zambia \\ Email: muzatakenneth@gmail.com
}

How to cite this paper: Muzata, K.K. (2018) Collaborative Responsibility in Teacher Preparation: Student Teachers' Perceptions of the Role of Schools in Their Professional Development in Zambia. Open Access Library Journal, 5: e4982.

https://doi.org/10.4236/oalib.1104982

Received: October 12, 2018

Accepted: October 28, 2018

Published: October 31, 2018

Copyright (๑) 2018 by author and Open Access Library Inc.

This work is licensed under the Creative Commons Attribution International License (CC BY 4.0).

http://creativecommons.org/licenses/by/4.0/

(c) (i) Open Access

\begin{abstract}
The aim of this study was to examine student teachers' perceptions of whether schools play a significant role in their professional development. The study employed a mixed-method design. Open and closed-ended questionnaire items were used to collect data from 74 student teachers that went for Teaching Practice from three different teacher education institutions in 2016. Simple random sampling was mainly applied when selecting respondents. Quantitative data were analyzed using the Statistical Package for Social Sciences (SPSS) to derive frequencies, percentages as well as differences and associations of the responses from the three institutions under study. Qualitative data were summed up in themes and findings related and compared with quantitative results. Results show that while students appreciated the guidance from schools, they had a large share of dissatisfaction as well. Students faced numerous system and administrative challenges that prohibited adequate practice time in schools. It was recommended that teacher education institutions establish collaboration with schools to help students benefit from mutual understanding about Teaching Practice.
\end{abstract}

\section{Subject Areas}

Education

\section{Keywords}

Collaboration, Schools, Student Teachers, Teacher Preparation, Teacher Professional Development, Teaching Practice 


\section{Background}

Teacher preparation is incomplete without Teaching Practice (TP). Everywhere in the world, teacher education is characterized by TP during the course of educating a teacher [1]. A student who fails TP does not graduate even though he or she may have superb abilities theoretically [2] [3]. Educating a teacher is a collaborative effort. [3] observed that an effective teacher-education programme can be ensured when both the school and the college administration work in collaboration. [4] encourages teacher education institutions to work closely and establish partnerships with schools to collaboratively build a student teacher. Universities and colleges of education have their roles of imparting theory related to teaching and learning in the classroom. However, schools are expected to closely guide the student teacher throughout the TP period.

In Zambia, teacher education is characterized by $\mathrm{TP}$ as one of the major assessment provisions leading to graduation. Student teachers in either the $2^{\text {nd }}, 3^{\text {rd }}$, or $4^{\text {th }}$ year depending on the institution and qualifications trained for, are deployed to schools to practice teaching. Lecturers go to observe students and help them acquire teaching competencies. [5] emphasized that:

"Higher education institutions, schools and students should focus on the competencies of teaching throughout the whole period of initial training. The progressive development of these competencies should be monitored regularly during initial training. Their attainment at a level appropriate to newly qualified teachers should be the objective of every student taking a course of initial training" (p.3).

The expected competencies required to be developed by trainee teachers according to [5] [6] are subject knowledge, subject application, class management, assessment and pupil progress record-keeping and further professional development. According to [6], students need to be prepared even in interpersonal and social skills.

To assess the acquisition of teaching skills, length of TP period should be considered. In Zambia, TP period varies from institution to institution. During the phased out Zambia Teacher Education Course (ZATEC), one year was school-based while another year was for TP (experience) [6] [7]. Many stakeholders thought one year was not enough for theory although adequate for methodologies. Now the Ministry of General Education guides teacher education institutions to give student Teaching Practice not less than three months or one school term [8]. With such guidance, some institutions have two TP sessions in the second year and another in the third year for one term in each year. However, some institutions have continued to send students for TP for less than three months. Disparities in the length of TP duration disadvantage some students who only manage to do TP in a short time such as 8 weeks or less. For instance, research findings indicate that the University of Zambia (UNZA) graduate teachers are not good at methodologies although they are well vested in content [9] [10]. A well-qualified teacher should be grounded in both content and me- 
thodologies because it is the methodologies that are a vehicle for delivering the content.

\subsection{Statement of the Problem}

Research findings by [2] [10] and [11] say that TP period for UNZA students is very short. Further, findings say that UNZA students were better in content than methodologies compared to students from institutions that offer diplomas in teaching [11]. But the questions that remain unanswered are, "what are the students' perceptions about the guidance they receive from schools during TP?" Do schools provide the necessary and palpable guidance to student teachers during TP? This study sought to establish student teachers' perceptions about the nature of guidance provided by schools during $\mathrm{TP}$.

\subsection{Research Objectives}

This study was guided by the following objectives:

1) To establish the nature of guidance provided by schools to student teachers while on TP.

2) To examine student teachers' perceptions about the nature of guidance provided by schools during TP.

3) To establish the challenges student teachers face during TP.

\subsection{Research Questions}

The following questions helped to gather information about student perceptions of the roles played by schools in guiding them during TP:

1) What is the nature of the guidance provided to student teachers in schools during TP?

2) How do students perceive the guidance provided by schools during TP?

3) What challenges do student teachers face during TP?

\subsection{Significance of the Study}

The quality and effectiveness of an education system depends heavily on the quality of its teachers [12]. While it is well recognized that teacher education institutions have a responsibility to train teachers, the student teacher's life during TP is under the guidance of the school. This study is important in that it would help teacher education institutions establish professional collaboration with schools in the interest of student-teacher professional development. It would also help schools to realize their roles beyond teaching. Schools have a major responsibility of building student teachers.

\subsection{Theoretical Framework}

This study is informed by the Cognitive Apprenticeship Model. The Cognitive Apprenticeship Model explains the process by which learners learn from a more experienced person by way of cognitive and metacognitive skills and processes 
[13] [14] explain that:

"Cognitive apprenticeship is an example of how scaffolding can be used in classrooms. A traditional apprenticeship involves an apprentice learning from a master craftsman" (p. 280).

Thus, the apprentice (learner) has to observe, be coached and allowed to practice what he or she has been coached. The trainee teacher needs a model to learn teaching strategies from. "The typical apprentice begins by doing simple tasks, gradually becomes more skilled and finally engages in the most complex task" [14]. The Cognitive apprenticeship theory pioneered by Collins 1989 [15] is associated with Socio-Cultural Theory by Levy Vygotsky. When relating the Cognitive Apprenticeship Model to this study, it implies that student teachers on TP should exhibit skills taught to them by lecturers and skills they learn by observation, modelling, coaching, and scaffolding. They should also exhibit articulation and reflective skills during TP. The attainment of such skills is likely to be constrained by several factors in and outside the school system.

\section{Literature Review}

The role of the school in the TP of student teachers cannot be overemphasized. Schools play a very important role in the professional development of student teachers. According to [5]:

"Observing teachers in action is important not only at the start of training but also as the student teacher progresses and develops skills. It is essential that observation sessions are structured, focusing on a specific aspect so that the student teacher can tease out the elements that make up a lesson and modify and adapt what has been witnessed to suit a personal teaching style. Even when the student teacher has advanced to teaching whole lessons, it is still important to continue observing lessons. Early observations will provide student teachers with repertoires from which they can choose when linking activities together in their own lesson plans."

From [5], this perhaps is a gap worth finding out as to whether the observation required of students that go in teaching is structured for them or indeed whether students have learnt to structure what they would pick from the observed lessons. When observing experienced teachers, students are required to outline characteristics they wish to pick from the lesson they observe. The school has a critical role in mentorship of student teachers. Even without formal mentors, students still make relations with informal mentors from whom they usually benefit. A study by [16] revealed that students benefited from informal mentors emotionally and appreciated being connected to a new social context. According to [16], Norwegian students that were in TP benefited from both informal and formal mentors in building up their professional careers.

However, there are different contexts across the world. Institutions, schools and students face different challenges in reaching the standard expected of a well-trained teacher. [17] found that students face several challenges; among 
them the fact that the period for Teaching Practice was too short, lack of instructional materials and resources in schools, poor learning environments and over-crowded classrooms, difficulties preparing notes, inadequate Teaching Practice orientation of students before actual Teaching Practice, lack of provision of field trip/excursion when necessary and other challenges that bordered on relationships with experienced teachers and personal welfare challenges of accommodation and allowances. [18] in a study of student teachers' experiences of teaching practice at open and distance learning institution in South Africa warns that the quality of teachers can deteriorate with the increasing number of students needing placement in schools. According to [19] notable challenges to teaching practice were poor placement of students in schools that did not have adequate facilities for practice, rush assessment by lecturers or supervisors due to large numbers of students they have to observe within a short time and poor management in some schools characterized by lack of timetables and mentoring staff.

[19] divided challenges facing student teachers on TP in Kenya into geographical, administrative, professional, instructional, supervision, social and financial challenges. According to [19], the geographical challenges that student teachers faced were long distances to school, impassable roads and accommodation problems. Administrative challenges included rejection of student teachers and overload of student teachers with more lessons. On professional challenges, trainee teachers were overloaded by cooperating teachers. The lack of instructional materials and irregular, harsh and unfriendly supervision were reported as instructional challenges. Students further faced social and financial challenges such as the lack of respect from school teachers and lack of finances for upkeep during TP.

The reviewed challenges do not only inhibit the professional development of a teacher beginning his or her career but also frustrates them. [4] noted that teachers beginning a teaching career experience difficulties in discipline, classroom control and work overload. If not carefully handled, TP creates stress, uncertainty, frustration, and sometimes despair. Education systems should work towards addressing the challenges facing teacher preparation in order to enhance quality teacher preparation. [20] and [21] recommend that making student teacher mentoring support as part of principals and teacher training, and part of performance management would promote collective responsibility of student-teacher professional development during TP.

\section{Methodology}

This study employed a mixed methods approach using a trend descriptive survey design. According to [22] "trend studies are typically used to examine the perceptions of groups that are having or have had a shared experience at a particular time", and the researcher has no interest in documenting and showing whether such perceptions have changed over time. The aim of this study was to 
collect describable data about attitudes, beliefs, behaviors and perceptions on TP. This study targeted a group of students that were on TP in 2016 academic year. A questionnaire with open and close-ended questions was used to collect quantitative and qualitative data at the same time. Open-ended questions provide depth in respondents' responses by the use of own words [23] while the closed-ended questions collected quantitative data. In descriptive surveys, the majority of the responses are quantitative and summarized as ratings or as numbers of people choosing a given answer [22]. Seventy-four student teachers from three institutions of teacher education (the University of Zambia (UNZA = 27, Nkrumah University College (NUC $=17$ ) and Solwezi College of Education $(\mathrm{SOCE}=30)$ were sampled randomly.

The original aim was to involve equal samples from each institution but some questionnaires were not returned. For [24], a sample of thirty respondents is enough minimum to make a statistical analysis and make possible generalizations for a population under study. Data collected were analyzed using the Statistical Package for Social Science (SPSS) to derive frequencies, percentages and some significant differences to determine whether there were differences in the sampled responses from different institutions. Qualitative data were organized in themes. Quantitative and qualitative data were then compared and related in a convergent parallel format [25]. In order to adhere to ethical considerations, respondents were asked not to write their names on the questionnaires. Pseudonyms were also used for schools where respondents did their TP. This study was valid and reliable. The reliability of this study lies in the consistency of the results as collected from three different places and institutions at different times. From the results, what the study was intended to measure was measured. Reliability of the instruments was determined through the Cronbach alpha test which showed internal consistency of.760 for eleven (11) items.

\section{Findings and Discussion}

The presentation and discussion of the results are guided by the nature of questions used to collect data. The main questions that guided the study were:

1) What is the nature of guidance provided to student teachers during TP?

2) How do students perceive the guidance provided by schools during TP?

3) What challenges do student teachers face during TP?

\subsection{Nature of Guidance Provided by Schools}

Students were first asked whether they received guidance from schools during TP. Figure 1 shows the results:

The results in Figure 1 show student satisfaction with the nature of help they received from practicing schools. Thus $87.8 \%$ (65) said they received adequate professional guidance from schools of practice while $8.1 \%$ (6) said they did not.

Students received help from Heads of Departments (HODs), Heads of Sections (HOSs) and experienced teachers. Table 1 shows the roles schools played 
in guiding students.

Generally, schools provided guidance to students through HODs and HOSs and experienced teachers being observed in teaching and observing students teaching. Allowing students to observe experienced teachers is clearly advised for students before they start teaching. This provides confidence and model behavior to the students. Schools' provision of feedback is crucial to the professional development of student teachers.

However, these results do not reflect the same satisfaction levels when students were asked about specific areas of guidance.

\subsection{Student Perceptions about the Nature of Guidance on Specific Pedagogical Areas}

The results further show that students appreciated schools' support in their professional development. Table 2 below shows a comparison of students from the three institutions reporting the areas of pedagogy in which they received professional help.

Coming up with a lesson title is not that easy especially for students on TP. In this study, most students $(66.2 \%)$ showed that they were not helped enough on how to come up with a lesson title. There were no significant differences $\left(\left(\chi^{2}(2\right.\right.$, $n=74)=1.98, p>0.05)$, between students from the three different institutions. The results show clearly that SOCE students $(76.7 \%)$ were more vulnerable in this regard, followed by UNZA (63\%) and NUC (58.8\%).

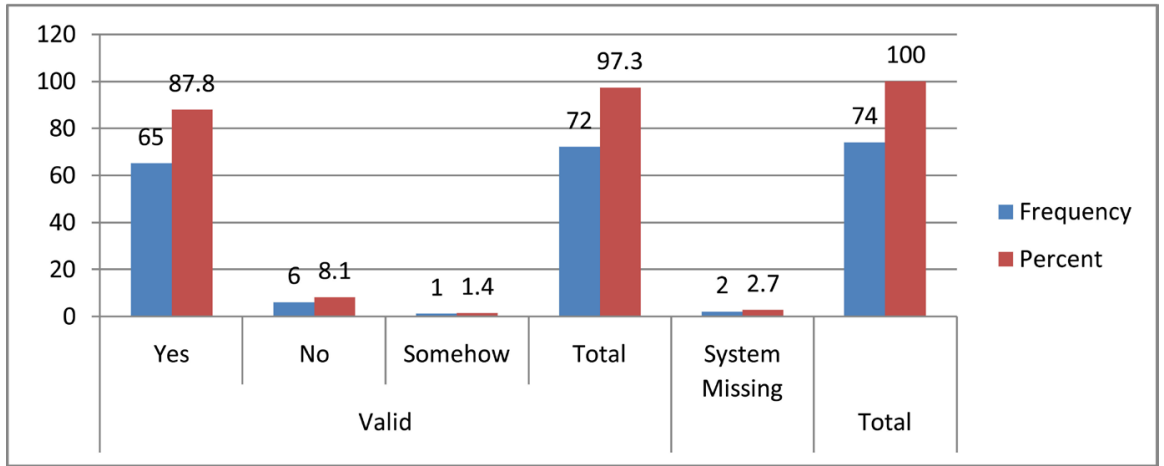

Figure 1. Whether students received guidance from the school.

Table 1. Roles played by the school through departments and sections.

\begin{tabular}{|c|c|c|c|c|c|c|}
\hline Characteristic & Yes & $\%$ & NO & $\%$ & $\begin{array}{l}\text { Missing } \\
\text { System }\end{array}$ & $\%$ \\
\hline $\begin{array}{l}\text { Received enough help from HOD } \\
\text { or HOS in their specialized subjects }\end{array}$ & 58 & 78.4 & 9 & 12.2 & 7 & 9.5 \\
\hline 2 Students first observed experienced teachers & 60 & 81.1 & 12 & 16.2 & 2 & 2.7 \\
\hline 3 Experienced teachers observed students & 69 & 93.2 & 3 & 4.1 & 2 & 2.7 \\
\hline $\begin{array}{l}\text { Experienced teachers provided written } \\
\text { feedback to students }\end{array}$ & 52 & 70.3 & 13 & 17.6 & 9 & 12.2 \\
\hline
\end{tabular}


Table 2. Guidance on lesson preparation and administration.

\begin{tabular}{|c|c|c|c|c|c|c|c|}
\hline \multirow{2}{*}{ Characteristic } & \multirow{2}{*}{ Institution } & \multicolumn{3}{|c|}{ Frequency \& Percentage } & \multirow{2}{*}{$\%$} & \multirow{2}{*}{ Total } & \multirow{2}{*}{$\%$} \\
\hline & & Yes & $\%$ & No & & & \\
\hline \multirow[t]{3}{*}{ Formulating lesson title } & SOCE & 7 & 23.3 & 23 & 76.7 & 30 & \\
\hline & NUC & 7 & 41.2 & 10 & 58.8 & 17 & \\
\hline & UNZA & 10 & 37 & 17 & 63 & 27 & \\
\hline$p$-value $=0.370$ & Total & 24 & 33.8 & 50 & 66.2 & 74 & 100 \\
\hline \multirow[t]{3}{*}{ Formulating objectives } & SOCE & 16 & 53.3 & 14 & 46.7 & 30 & \\
\hline & NUC & 11 & 64.7 & 6 & 35.3 & 17 & \\
\hline & UNZA & 13 & 48.1 & 14 & 51.6 & 27 & \\
\hline$p$-value $=0.559$ & Total & 40 & 55.4 & 34 & 44.5 & 74 & 100 \\
\hline \multirow[t]{3}{*}{ Lesson introduction } & SOCE & 9 & 30 & 21 & 70 & 30 & \\
\hline & NUC & 8 & 52.9 & 7 & 47.1 & 15 & \\
\hline & UNZA & 12 & 44.4 & 15 & 55.6 & 27 & \\
\hline$p$-value $=0.267$ & Total; (missing 2) & 29 & 42.4 & 43 & 57.6 & 72 & 100 \\
\hline \multirow[t]{3}{*}{ Lesson development } & SOCE & 9 & 30 & 21 & 70 & 30 & \\
\hline & NUC & 9 & 52.9 & 8 & 47.1 & 17 & \\
\hline & UNZA & 15 & 55.6 & 12 & 44.4 & 27 & \\
\hline$p$-value $=0.112$ & Total & 33 & 46.2 & 41 & 53.8 & 74 & 100 \\
\hline \multirow[t]{3}{*}{ Conclusion } & SOCE & 12 & 40 & 18 & 60 & 30 & \\
\hline & NUC & 9 & 52.9 & 8 & 47.1 & 17 & \\
\hline & UNZA & 15 & 55.6 & 12 & 44.4 & 27 & \\
\hline$p$-value $=0.463$ & Total & 36 & 49.5 & 38 & 50.5 & 74 & 100 \\
\hline \multirow[t]{3}{*}{ Lesson evaluation } & SOCE & 18 & 60 & 12 & 40 & 30 & \\
\hline & NUC & 10 & 58.8 & 7 & 41.2 & 17 & \\
\hline & UNZA & 12 & 44.4 & 15 & 55.6 & 27 & \\
\hline$p$-value $=0.452$ & Total & 40 & 54.4 & 34 & 45.6 & 74 & 100 \\
\hline
\end{tabular}

On coming up with lesson objectives, no significant differences between students from different institutions were reported from Chi-square test results at $\left(\chi^{2}(2, n=74)=1.16, p>0.05\right)$. Students $55.4 \%$ (40) seem to indicate that they were helped on how to come up with lesson objectives while $44.5 \%$ (34) said they were not helped. Although there weren't significant differences, most students from UNZA, $51.6 \%$ (14) said they were adequately helped in this area. 
Another critical area of a lesson plan is lesson introduction. Generally, students $57.6 \%$ (43) said they were not helped enough, and no significant differences were recorded with Chi-square test showing $\left(\chi^{2}(2, n=74)=2.64, p>\right.$ $0.05)$, giving an indication that students from the three institutions did not benefit much from professional help on how to introduce a lesson attractively.

The actual teaching and demonstration of content and methodologies by student teachers are demonstrated during lesson development. The results of this study show that students, $53.8 \%$ (41) were not helped enough on lesson development. This is consistent with chi-square computation which showed no significant differences in the results from the respondents from the three institutions, $\left(\chi^{2}(2, n=74)=4.38, p>0.05\right)$.

On how best to conclude a lesson, chi-square results show differences at $\left(\chi^{2}(2\right.$, $n=74)=1.54, p>0.05)$ between the different institutions where respondents were drawn. However, $50.5 \%$ (38) of the students said they received adequate help on how to conclude the lesson while; $49.5 \%$ (36) said they were not. The difference between those who agreed and disagreed is $1 \%$, meaning there is need to pay particular attention to this part as well when guiding student teachers.

Lesson evaluation is a reflection of a good teacher. A teacher should be able to tell whether his or her learners have achieved the objectives or not. Student teachers need quality guidance in this area. When responses from the three institutions were compared on a chi-square test, students reported that they were adequately helped on how to evaluate lessons, $\left(\chi^{2}(2, n=74)=1.59, p>0.05\right)$ showing no significant differences (see p-value in Table 2). However, the number of students; (45.6\% or 34 students) who said they did not get adequate help was equally high, and cannot be ignored. This is why the chi-square calculation shows no significant differences and ignoring such results and thinking the students are doing well would be illusionary and a compromise to quality teacher education.

The students were further asked on whether they received adequate professional guidance on how to arrange the Teaching File. The results show no significant differences among respondents from the three institutions at $\left(\chi^{2}(2, n=\right.$ $74)=4.10, p>0.05)$. Overly, 59.7\% (44) students said they were not guided enough on teaching file order and the most vulnerable students in this area were from the SOCE $70 \%$ (21) followed by NUC at $64.7 \%$ (11). As the chi-square test results show, this is a general concern for students from all the three institutions (Table 3).

On Teaching File, key documents that are expected to be seen are plans of lessons already taught, schemes of work, records of work and other necessary documentation such as assessment records. Students were asked whether they were guided on lesson plans, schemes of work and records of work. On filed lesson plans, a significant difference was noted through the chi-square test $\left(\chi^{2}(2, n\right.$ $=74)=7.80, p<0.05)$. This mainly affected SOCE as $80 \%(24)$ of the respondents said they were not guided in this area. The strength of the relationship is at phi [ $\emptyset]$ $=0.325$, slightly above medium of size effect. There were, however, no significant 
Table 3. Guidance on the teaching file.

\begin{tabular}{|c|c|c|c|c|c|c|c|}
\hline Characteristic & Institution & Frequency & $\%$ & Frequency & $\%$ & Total (F) & Total (\%) \\
\hline \multirow[t]{3}{*}{ Teaching file order } & SOCE & 9 & 30 & 21 & 70 & 30 & \\
\hline & NUC & 6 & 35.3 & 11 & 64.7 & 17 & \\
\hline & UNZA & 15 & 55.6 & 12 & 44.4 & 27 & \\
\hline$p$-value $=0.129$ & Total & 30 & 40.3 & 44 & 59.7 & 74 & 100 \\
\hline \multirow[t]{3}{*}{ Teaching file lesson plans } & SOCE & 6 & 20 & 24 & 80 & 30 & \\
\hline & NUC & 9 & 52.9 & 8 & 47.1 & 17 & \\
\hline & UNZA & 14 & 51.9 & 13 & 48.1 & 27 & \\
\hline$p$-value $=0.020$ & Total & 29 & 41.6 & 45 & 58.4 & 74 & 100 \\
\hline \multirow[t]{3}{*}{ Schemes of work } & SOCE & 6 & 20 & 24 & 80 & 30 & \\
\hline & NUC & 8 & 47.1 & 9 & 52.9 & 17 & \\
\hline & UNZA & 12 & 44.4 & 15 & 55.6 & 27 & \\
\hline$p$-value $=0.078$ & Total & 26 & 37.2 & 48 & 62.8 & 74 & 100 \\
\hline \multirow[t]{3}{*}{ Records of work } & SOCE & 14 & 46.7 & 16 & 53.3 & 30 & \\
\hline & NUC & 7 & 41.2 & 10 & 58.8 & 17 & \\
\hline & UNZA & 12 & 44.4 & 15 & 55.6 & 27 & \\
\hline$p$-value $=0.936$ & Total & 33 & 44.1 & 41 & 55.9 & 74 & 100 \\
\hline
\end{tabular}

differences among students on whether they were guided on the schemes of work or not at $\left(\chi^{2}(2, n=74)=5.10, p>0.05\right)$ with most students $(62.8 \%)$ saying that they were not well guided. On records of work, most students; $55.9 \%$ (41), also said that they were not guided $\left(\chi^{2}(2, n=74)=1.33, p>0.05\right)$ showing no significant differences.

Overall, the average percentage of whether students received guidance on all the ten itemised features of pedagogy, shows that $44.5 \%$ received professional help from schools in various pedagogical areas and $55.5 \%$ did not agree. This shows the need to provide effective professional development to students in colleges and universities. The results show that all students from the different teacher education institutions faced the same difficulties. However, despite expressing some degree of dissatisfaction about the nature of guidance received during TP, students endorsed schools as the better to guide them and develop them professionally than their lecturers. When asked whether they were better guided by school staff or lecturers, Table 4 shows the results.

Most students said they gained more help from school staff than from the lecturers that visited and observed them. These results are similar to those by [17] among Norwegian student teachers which showed that students appreciated being observed by mentors, arguing it has more advantages in building them in their professional careers. Reasons here are simply that school staff were within reach and were able to be consulted any time during working hours. Students had more time with school staff and developed interpersonal relationships that 
enabled them to also fit into the communities they served. This calls for empowering school teachers with mentoring skills.

\subsection{Challenges Student Teachers Faced during TP}

\subsubsection{Short TP Period}

Respondents were asked for their views on the length of TP and whether they thought it was adequate for practice or not. Table 5 shows that some students (36.5\%) still said the period was not adequate enough for TP.

Students from SOCE and NUC said that the period for TP was adequate. Students from the university mainly said that the 8 weeks period of TP was not enough because usually the first week was mostly for settling in. "It's like I only spent 4 weeks in teaching because the first two weeks were for settling in and the last two for tests," wrote a respondent. Another respondent wrote, "I only taught for four weeks because our Teaching Practice took 6 weeks. Week one and six were used for settling down and test respectively". "I was supposed to teach even for two terms so that I will have more experience". "Because the period was short such that the time I was getting used to teaching, my time was over." "I feel the period was too short, I still needed more time to enjoy my experience". These findings are similar to the findings by [2] [11], and [9] who reported that TP for UNZA students was too short, not effective and students did not receive help from lecturers and cooperating schools. The concern about shortness of TP period may not be peculiar to Zambia. [18] in Benin, found that among the challenges which included the lack of teaching and learning materials, students said the TP period was too short. The same challenge was reported by [26], about Vaal University students in South Africa who reported that they were posted for TP too late in the year when most teachers had completed their syllabus and revising for examinations. The best times for students to be sent for TP

Table 4. Students' views on who best guides them between school teachers and lecturer.

\begin{tabular}{|c|c|c|c|}
\hline & & Frequency & Per cent \\
\hline & School staff & 44 & 59.5 \\
\hline \multirow{3}{*}{ Valid } & Lecturers & 22 & 29.7 \\
\hline & Both & 4 & 5.4 \\
\hline & Total & 70 & 94.6 \\
\hline \multirow[t]{2}{*}{ Missing } & System & 4 & 5.4 \\
\hline & & 74 & 100 \\
\hline
\end{tabular}

Table 5. Is TP long enough or not?

\begin{tabular}{cccc}
\hline & & Frequency & Per cent \\
\hline \multirow{3}{*}{ Valid } & Enough & 47 & 63.5 \\
& Not enough & 27 & 36.5 \\
& Total & 74 & 100 \\
\hline
\end{tabular}


are first and second terms of the school calendar. The third term, especially in Zambian school calendar, is characterized by disturbances related to preparations for examinations. This denies students adequate time to practice teaching.

\subsubsection{Student Settling for TP}

Students reported that they took quite a long time to settle in schools during TP. Failure to settle in quickly further worsened the problem of shortened TP period for students from UNZA. The results showed that $62 \%$ (46) of the students only settled for TP in 1 to 5 days, while 28\% (21) took about 6 to 10 days before they could settle. Seven respondents, $9 \%$ (7) of the students only settled after 11 to 20 days. In this case, if a student settles after 20 days and TP period is 8 weeks, the student is likely to practice only for 36 days ( 5 weeks). This could be the reason Simuyaba et al., (2015) said TP for UNZA students was six (6) weeks. It is difficult to put into practice skills learnt in the university in 5 weeks of TP. Such can be termed as pseudo practice.

\subsubsection{Challenges Related to Working with Experienced Teachers}

Students also faced numerous challenges working with experienced teachers as in the following extracts from open-ended questions:

- Some experienced teachers were not social and friendly for consultation.

- Lack of respect by some experienced teachers.

- Experienced teachers were hiding textbooks, they were selfish.

- During month ends, experienced teachers all left school for payday leaving burdens on trainee teachers.

- Some experienced teachers were not cooperative, they thought they knew it all.

- Trainee teachers being segregated because experienced teachers thought students from a named university were arrogant.

- Some experienced teachers were not willing to help student teachers.

- Receiving love proposals from married teachers.

- Experienced teachers were too bossy.

- Experienced teachers worked like they were competing to teach with trainee teachers.

- Some experienced teachers felt inferior to students who were studying for a degree because they themselves were diploma holders.

- Experienced teachers used to underrate trainee teachers saying they were incompetent.

- Both experienced and trainee teachers had difficulties adapting to the new curriculum.

From the results, the researcher observes the need for a strong student support system to ensure effective TP. This strong support calls for collaborative effort and a pull of not only material resources but also intellectual, emotional and social resources. A strong support system for student teachers is demonstrated in Figure 2. 


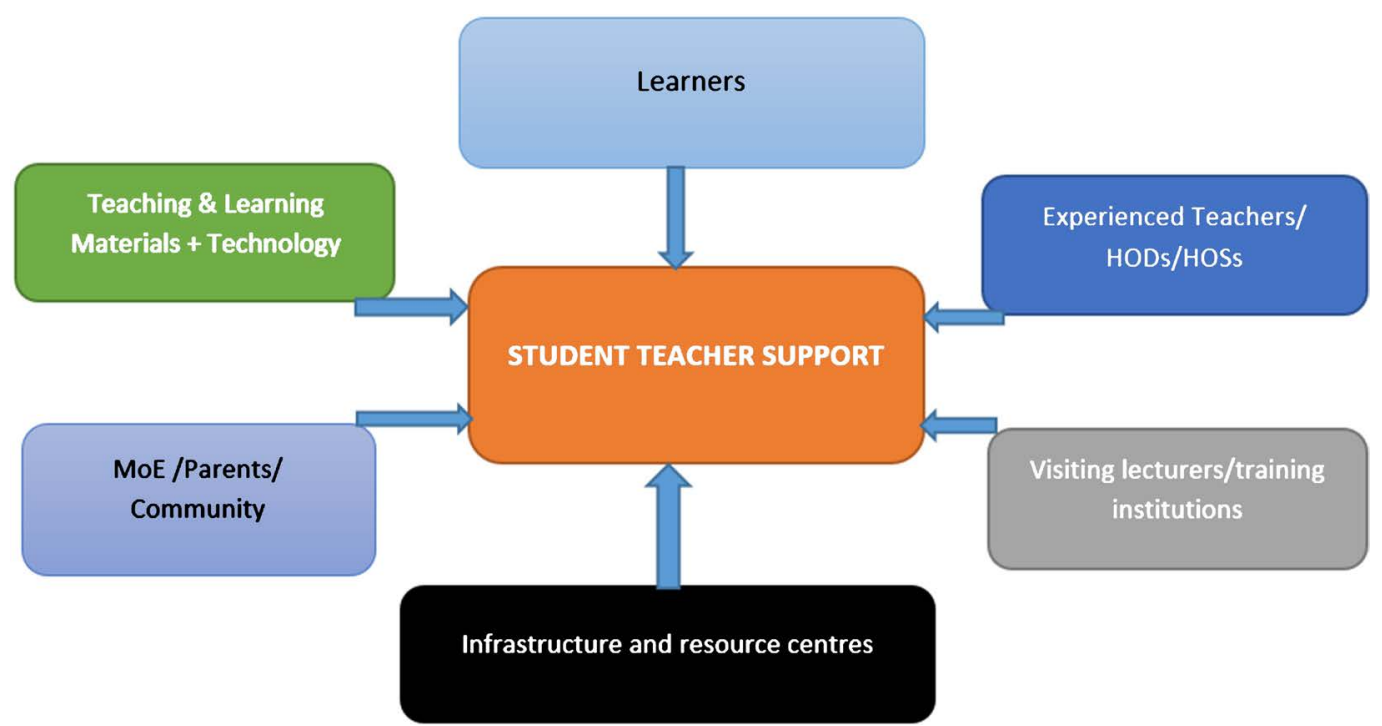

Source: Author.

Figure 2. Support systems for students on TP.

In the above framework in Figure 2, the student is the focus at the centre of professional guidance. Without any of the support systems, the student is left to wonder whether his or her professional expectations would be met or not. For instance, the school as a receiving institution determines whether a new teacher is welcome or not. Since schools are the hosts, they need to know well in advance that they are receiving students so they can prepare for the arrival of the student teachers well in advance. Before a student is sent to the school for TP, a link should be established between the teacher education institution and the school. This link shows understanding of the nature of help the students should receive once posted. This link helps prepare schools for positive attitudes, and physical support for the student teacher. In this study, some students reported that some experienced teachers were not sociable, did not open up for consultation, did not respect them and called them by derogatory names. These are challenges related to attitudes. From the results, it can be postulated that some of the challenges relate much to the lack of preparation by the schools to receive student teachers.

Learners are key stakeholders in the school. Learners can build or destroy a teacher. In this study, some student teachers complained that they were not respected by learners, an aspect that was also attributed to experienced teachers influencing learners to regard student teachers as such. One of the respondents said,

"I was not happy when I was introduced as a student and the pupils jeered aloud".

Such a problem is created by the school. A school must have values to promote. A school is not expected to be in the forefront of promoting discordant behavior among learners. While it is understood that student teachers are students, they are teachers to learners even during TP. They deserve respect. [26] reported that student teachers from Vaal University in South Africa appreciated 
mentors who treated them with respect. When students feel un-respected, they may go against the ethos of teaching and teach to appease or show in order to gain respect. One student wrote;

"Teaching Practice was a period of teaching competition between us and_experienced teachers".

Another wrote,

"Teaching was like a competition because most teachers were diploma holders".

Similar to this behavior, [9] reported a lack of collaboration between student teachers and serving teachers during TP. Once a competitive attitude is created during TP, students may avoid using learner-centered approaches they have learned and resort to teacher-centered methods in order to show that they understand the content.

The challenges of poor infrastructure, over-enrolled classrooms, lack of teaching and learning resources are system challenges that are beyond a student's control and require the Ministry of General Education to pay particular attention to addressing such challenges. Schools, however, have a role to structure TP for student teachers in a manner that does not create pressure handing overcrowded classes by students who need to practice learner-centered methods on small numbers. Effective TP calls for teaching resources, otherwise, student teachers would abhor the profession. It was astonishing to discover that student teachers faced challenges because they found a new curriculum in schools yet they were trained on an old curriculum. One student wrote:

"Teaching is a very frustrating profession, there is no allowance, no teaching materials, and I have to fight for myself on everything".

Such expressions though real, are not wondrous to the teaching profession. The provision of effective teacher education requires all stakeholders and especially the Ministry of General Education to be on top of things.

\section{Conclusion}

The study concludes that although efforts were being made by schools to guide student teachers during TP, an aspect that student teachers appreciated compared to the guidance received from lecturers, a number of challenges constrained the quality of guidance students received. There were no significant differences among the three institutions with regard to the challenges students faced during TP. The challenges which affected both schools and students include short TP period, lack of coordination between teacher education institutions and schools, leading to students failing to settle down quickly for TP.

\section{Recommendations}

Following the results of this study, the following were the recommendations;

1) TP period should not be less than 3 months or one school term as reflected in [8]. Lengthened period of TP coupled with practice based experience would 
help train quality teachers through TP [27]. This should be implemented in all teacher training institutions as a directive.

2) Teacher education institutions should create strong links with schools and provide the necessary skills for schools to be able to, in turn, provide effective professional development to student teachers. This can include the training of experienced teachers in student mentorship.

3) Teacher education institutions should align their curriculum with school curricula to avoid disparities in what students train in and what they find in the schools where they are posted for teaching practice.

4) The Ministry of General Education should design effective support system for student teachers to be able to practice teaching effectively. This can include meeting students' basic needs such as food and transport allowances, accommodation and addressing the shortage of teaching and learning materials besides classroom overcrowding.

\section{Conflicts of Interest}

The author declares no conflicts of interest regarding the publication of this paper.

\section{References}

[1] Maphalala, M.C. (2013) Understanding the Role of Mentor Teachers during Teaching Practice Teaching Practice Session. International Journal of Education Sciences, 5, 123-130. https://doi.org/10.1080/09751122.2013.11890069

[2] Muzata, K.K. and Penda, A. (2014) Pedagogical Experiences of Students on School Teaching Practice Teaching Practice: A Study of Two Teacher Training Institutions on the Copper Belt and Central Provinces of Zambia. International Journal of Sciences. Basic and Applied Research (IJSBAR), 14, 187-204.

[3] Githinji, J.N., Nderitu, J. and Mugailwa, E. (2013) Teaching Practice Teaching Practice Assessment in Kenyan Teacher Training Colleges: Towards Bridging Theory and Practice for Teacher Quality Improvement. Journal of Educational Assessment in Africa, 8, 2013.

[4] Bezzina, C. and Michalak, J. (2009) Preparing Student Teachers for Teaching Practicum. In: Swennen, A. and Klink, M.V., Eds., Ch. 11 Becoming a Teacher Educator Theory and Practice for Teacher Educators, Springer, Amsterdam.

[5] Monk, M. and Dillon, J. (2005) Learning to Teach Science: Activities for Students and Mentors. Taylor \& Francis E-Library, Milton Park, Abingdon-on-Thames, Oxfordshire United Kingdom.

[6] Musonda, W.L. (1999) Teacher Education Reform in Zambia... Is It a Case of a Square Peg in a Round Hole? Journal of Teaching and Teacher Education, 15, 157-168. https://doi.org/10.1016/S0742-051X(98)00056-0

[7] Kalimaposo, K.K. (2010) The Impact of Curriculum Innovations on Pre-Service Primary Teacher Education in Zambia. A Thesis Submitted for the Degree of Doctor of Philosophy in Sociology of Education of the University of Zambia.

[8] MESVTEE (2013) The Zambia Education Curriculum Framework. CDC, Lusaka.

[9] Manchishi, P.C. and Mwanza, D.S. (2013) The University of Zambia School Teaching Experience: Is It Effective? Excellence in Higher Education, 4, 61-77. https://doi.org/10.5195/EHE.2013.84 
[10] Banja, M.K. (2012) The Relevance and Adequacy of University Education to Occupational Demands: The Case of Zambia. Zango Journal of Contemporary Issues, 29, 1-8.

[11] Simuyaba, E., Banda, D., Mweemba, L. and Muleya, G. (2015) Theory against Practice: Training of Teachers in a Vacuum. Journal of Education and Social Policy, 2 , 88-99.

[12] Ministry of Education (2010) Education Sector-National Implementation Framework Iii 2011-2015, Education for All: Accelerating Poverty through Rural Investment, Human Capital And Infrastructure Development. Ministry of Education, Lusaka.

[13] Vanessa, P., Dennen, V.P. and Burner, K.J. (n.d.) The Cognitive Apprenticeship Model in Educational Practice. University of Florida, Florida.

[14] O’Donnel, A.M., Reeves, J. and Smith, J.K. (2012) Educational Psychology: Reflection for Action. John Wiley \& Sons Inc., Canada.

[15] Hennessy, S. (1993) Situated Cognition and Cognitive Apprenticeship: Implications for Classroom Learning. Studies in Science Education, 22, 1-41.

https://doi.org/10.1080/03057269308560019

[16] Desimone, L.M., Hochberg, E.D., Porter, A.C., Polikoff, M.S., Schwartz, R. and Johnson, L.J. (2014) Formal and Informal Mentoring: Complementary, Complementary, Compensatory or Consistent? Journal of Teacher Education, 65, 88-110. https://doi.org/10.1177/0022487113511643

[17] Okobia, E.O., Augustine, E.O. and Osagie, O.R. (2013) An Analysis of the Perceived Challenges Faced By Student-Teachers during Teaching Practice Teaching Practice Exercise. Journal of Education and Practice, 4, 7-11.

[18] Mokoena, S. (2017) Student Teachers' Experiences of Teaching Practice at Open and Distance Learning Institution in South Africa. Turkish Online Journal of Distance Education, 18, 122-133. https://doi.org/10.17718/tojde.306564

[19] Koross, R. (2016) The Student Teachers' Experiences during Teaching Practice and Its Impact on Their Perception of the Teaching Profession. IRA-International Journal of Education \& Multidisciplinary Studies, 5, 76-85. https://doi.org/10.21013/jems.v5.n2.p3

[20] Mukeredzi, T.G. and Mandrona, A.R. (2013) The Journey to Becoming Professionals: Student Teachers' Experiences of Teaching Practice in a Rural South African Context. International Journal of Educational Research, 62, 141-151. https://doi.org/10.1016/j.ijer.2013.07.010

[21] Mukeredzi, G.T. (2014) Re-Envisioning Teaching Practice: Student Teacher Learning in a Cohort Model Practicum in a Rural South African Context. International Journal of Education Development, 39, 100-109. https://doi.org/10.1016/j.ijedudev.2014.08.010

[22] Lodico, A.G., Spaulding, D.T. and Voegtle, K.H. (2006) Methods in Educational Research: From Theory to Practice. Jossey-Bass, San Francisco.

[23] Mukherji, P. and Albon, D. (2015) Research Methods in Early Childhood: An Introductory Guide. SAGE, London.

[24] Cohen, L., Manion, L. and Marrison, K. (2000) Research Methods in Education. Routledge Falmer, London. https://doi.org/10.4324/9780203224342

[25] Creswell, J.W. (2014) Research Design: Qualitative, Quantitative and Mixed Methods Approaches. SAGE Publications Limited, UK.

[26] Kiggundu, E. and Nayimuli, S. (2009) Teaching Practice Teaching Practice: A Make 
or Break Phase for Student Teachers. South African Journal of Education, 29, 345-358.

[27] Muzata, K.K. (2018) Teaching Skills of Special Education Students during Teaching Practice: The Case of the University of Zambia Preservice Special Education Students. Multidisciplinary Journal of Language and Social Sciences Education, 1, 103-137. 